\title{
Health and Leisure of Workers of Day and Night Shifts
}

\section{SALUD Y OCIO DE LOS TRABAJADORES DE LOS TURNOS DE DÍA Y NOCHE}

\author{
Rubian Diego Andrade', Geraldo Jose Ferrari Junior ${ }^{1}$, Diego Grasel Barbosa', Clarissa Stefani Teixeira², Thais Silva Beltrame ${ }^{1}$, \\ Érico Pereira Gomes Felden' \\ 1. Universidade do Estado de Santa Catarina (UDESC), Florianópolis, SC, Brasil. \\ 2. Universidade Federal de Santa Catarina (UFSC), Florianópolis, SC, Brasil.
}

\section{RESUMEN}

Objetivo: analizar las diferencias en salud, ocio y trabajo según el turno de trabajo en trabajadores de la industria de Florianópolis, Brasil. Método: los participantes fueron 885 trabajadores en el turno de trabajo fijo (649 del turno general, 101 del primer turno, 84 del segundo turno y 51 del tercer turno). La salud se investigó utilizando el Cuestionario Internacional de Actividad Física - Forma Corta (IPAQ-SF), el Índice de Calidad de Sueño de Pittsburgh (PSQI) y el cuestionario de mañana y noche de Horne-Ostberg para actividad física, calidad del sueño y cronotipo, respectivamente. Las actividades de ocio se investigaron en función de la Escala de prácticas en el ocio (Escala de Práticas no Lazer - EPL). Para calcular la diferencia entre medias, se utilizó la prueba de Kruskall-Wallis (Dunn o Student-Newman-Keuls post hoc) y la prueba de chi-cuadrado. En el análisis de correlación entre variables continuas, se utilizó la prueba de Spearman. Los datos se analizaron utilizando los softwares SPSS 20.0, BioEstat 5.0 y GPower 3.0. Se adoptó un nivel de significancia del 5\%. Resultados: la edad promedio de los trabajadores fue de $31,1(8,5)$ años, y el 58,0\% fueron mujeres. Se identificaron diferencias significativas entre los turnos de trabajo con respecto a la calidad del sueño ( $p<0,001$ ), con una prevalencia del $35,6 \%$ de los trastornos del sueño en el turno de la noche. Entre estos, el 16,7\% mostró características matinal y el 68,6\% informó ausencia del trabajo por razones de salud en el último año. El consumo de bebidas con cafeína $(33,3 \%)$ y cigarrillos $(21,6 \%)$ también fue mayor entre los trabajadores del turno nocturno. Sin embargo, el tiempo en la actividad física vigorosa fue mayor, con un promedio de 75,5 minutos por semana. Además, los trabajadores del turno de noche tenían ingresos más bajos $(p<0,001)$ y buscaban un segundo trabajo para complementarlos $(p=0,002)$. Entre los temas relacionados con el ocio, se identificaron diferencias en el contenido artístico $(p=0,046)$, físico-deportivo ( $p=$ $0,048)$ y turístico $(p=0,004)$. Conclusión: las diferencias sustanciales en cuanto a trabajo, salud y ocio se evidenciaron en diferentes turnos, especialmente en el turno de noche. Aunque, teóricamente, hay más tiempo para las actividades de ocio, los trabajadores del turno de noche buscan un segundo empleo para la complementación de ingresos. El exceso de trabajo asociado al despertarse por la noche y los comportamientos de riesgo resultan en daños a la salud y al ocio.

(Andrade RD, Ferrari Junior GJ, Barbosa DG, Teixeira CS, Beltrame TS, Felden ÉPG, 2017. Salud y Ocio de los Trabajadores de los Turnos de Día y Noche. Cienc Trab. Sep-Dic; 19 [60]: 143-150).

Palabras clave: TURNO DE TRABAJO, SALUD LABORAL, ACTIVIDADES DE OCIO.

Correspondencia / Correspondence:

Rubian Diego Andrade

CEFID/UDESC Rua Paschoal Simoni 358, Florianópolis

SC, Brasil CEP: 88080-350

Tel.: 48-3321-860

e-mail: rubiandiego@gmail.com

Recibido: 12 de Septiembre 2017 / Aceptado: 14 de Noviembre de 2017.

\section{ABSTRACT}

Objective: To analyze differences in health, leisure and work according to work shift in industry workers of Florianopolis, Brazil. Method: participants were 885 workers on fixed work shift (649 of the general shift, 101 of the 1 st shift, 84 of the 2 nd shift and 51 of the $3 \mathrm{rd}$ shift). Health was investigated using the International Physical Activity Questionnaire - Short Form (IPAQ-SF), the Pittsburgh Sleep Quality Index (PSQI) and the Horne-Ostberg morningness and eveningness questionnaire for physical activity, sleep quality and chronotype, respectively. Leisure activities were investigated based on the Scale of practices in leisure (Escala de Práticas no Lazer - EPL). To calculate difference between means, the Kruskall-Wallis test (Dunn or Student-Newman-Keuls post hoc) and the chi-square test were used. In the correlation analysis among continuous variables, the Spearman test was used. Data were analyzed using SPSS 20.0, BioEstat 5.0 and GPower 3.0 softwares. A 5\% significance level was adopted. Results: The average age of workers was 31.1 (8.5) years, and 58.0\% were female. Significant differences among work shifts with respect to sleep quality $(\mathrm{p}<0.001)$ were identified, with prevalence of $35.6 \%$ of sleep disorders in the night shift. Among these, 16.7\% showed morning characteristics and 68.6\% reported absence from work for health reasons in the last year. The consumption of caffeinated beverages (33.3\%) and cigarettes (21.6\%) were also higher among night shift workers. Nevertheless, the time in vigorous physical activity was higher, averaging 75.5 minutes per week. Furthermore, night shift workers had lower income $(p<0.001)$ and seek a second job for income complementation ( $\mathrm{p}=0.002)$. Among issues related to leisure, differences in artistic ( $p=0.046)$, physical-sport ( $p=0.048)$ and touristic content $(p=0.004)$ were identified. Conclusion: substantial differences regarding labor, health and leisure issues were evidenced in different shifts, especially in the night shift. Although, theoretically, there is more time for leisure activities, night shift workers seek for a second job for income complementation. The excess of work associated with waking at night and risk behaviors result in damages to health and leisure.

Key words: WORK SHIFT, OCCUPATIONAL HEALTH, LEISURE ACTIVITIES.

\section{INTRODUCTION}

During the last centuries, the productive process has undergone modifications intensified with the rise of capitalism and industry. These changes led to changes in the division and forms of work organization, being no longer handmade and becoming automated. This leads, among other things, to the practice of fragmented and repetitive work. In addition, with the advent of the 
industrial revolution, the work was structured with the fulfillment of the working hours, and later, such labor organization was consolidated in a right for workers. ${ }^{1}$

With the globalization process, production speed has increased to meet the demand and market needs. This factor was essential for the expansion and division of shift work. Thus, shift work has been an alternative to provide production in industries beyond the provision of service such as safety, health, and others. It is estimated that in Europe and the United States, 14\% of workers are included in the context of shift work, especially in the night shift. ${ }^{2}$ Although there is no official data on the number of workers in this modality in Brazil, it is believed that this percentage is close to this value. $^{3}$ Thus, the society of the twenty-first century now operates 24 hours a day.

Overall, shift work is characterized as being any work performed at a time other than the formal schedule (daytime). It can be performed in fixed shifts (morning, afternoon or evening), work rotation (scales) or compressed cycles (usually in petrochemical companies) between eight to 12 hours. ${ }^{3}$

Concerning this new arrangement in the production mode, concerns about workers' health gain strength, especially with regard to night work. In this sense, there is evidence of substantial changes in the worker's life into three major areas: metabolic processes; physical health and psychological well-being, as well as adversities related to social and family life. ${ }^{4}$

Recent systematic review about endogenous metabolic processes triggered by shift work, especially at night shift, revealed changes in the concentrations of melatonin, cortisol, ghrelin and leptin hormones. ${ }^{5}$ These hormones play an important role in homeostasis and are closely associated with circadian rhythmicity. ${ }^{6}$ Thus, these "disturbances" in metabolic processes result in increased risk of diabetes and insensitivity to insulin impacting negatively on the sleep-wake cycle and consequently human health. ${ }^{7}$

Sleep disorders as result of inversion in work routines essentially consist essentially in decreased sleep quality, insomnia and increased excessive daytime sleepiness. ${ }^{8,9}$ Furthermore, given the concern about disorders related to shift work, the International Agency for Research on Cancer, based on evidence from animal studies, classified shift work as a "risk factor for cancer in humans". ${ }^{10}$ Thus, night work stands out as one of the significant factors in the health-disease process in humans.

Still regarding the night work, years of trading nighttime sleep by work has reflected in gastric and intestinal damage, obesity and maintenance of habits such as smoking and alcohol consumption. ${ }^{11}$ Ulhoa et al ${ }^{5}$ showed scientific evidence, because of research carried out in the last ten years that shift work may adversely affect eating habits and stress.

In addition, other issues such as social and family life are also associated with shift work ${ }^{12}$ as the participation of these workers in family events is impaired, especially in the evening due to their work shift. ${ }^{4}$ Similarly, leisure practices, as an important cultural phenomenon, are harmed due to shift work because such activities are performed as opposed to formal work commitments (nights and weekends). ${ }^{13}$ Thus, many night workers have limited leisure practices.

Nevertheless, work has a great function that goes beyond the exchange of labor for pay. Through this exchange, the worker gives a meaning to life and to social relations. It is therefore an important social role that keeps people within the context of society. ${ }^{1}$
Thus, considering work as a categorical factor in the health-disease process and the limitation in the description of leisure behavior in adults, this study aimed to analyze the differences in health issues, work, and leisure according to the work shift of industry workers of Florianopolis, SC - Brazil.

\section{METHOD}

This study is characterized as cross-sectional, and according to $\mathrm{Gil}^{14}$, as a descriptive research, because it will describe health issues and work and leisure preferences of workers. After this description, associations of these variables according to the work shift were verified.

\section{Participants}

The population considered for this study was 1.674 workers from the telecommunications segment (of these, 720 works in production and 954 in administrative sectors) of both sexes, hired under the CLT system (Consolidation of Brazilian Labor Laws), being in one of the major industries of Florianopolis (Brazil).

The company was selected due to its size and internal organization, which includes employees from different hierarchical positions and functions, and for being the only one in the region to maintain its production in four shifts, namely:

General shift: 1446 employees (492 production) and working schedule from 7:30 a.m. to 05:30 p.m.; 1st shift (morning): 78 workers, all from the production sector and working schedule from 05:50 a.m. to 02:20 p.m. from Monday through Friday and alternate Saturdays; 2nd shift (afternoon): 81 workers, all from the production sector and working schedule from 02:10 p.m. to 10:37 p.m., from Monday through Friday and alternate Saturdays; 3rd shift (night): 69 workers, all from the production sector and working schedule from 10:27 p.m. to 06:00 a.m. from Monday through Friday and alternate Sundays (data provided by the company).

Workers in this industry have working hours ranging from 36 to $44 \mathrm{~h}$ I week, fixed shifts, divided into sectors such as administrative, consisting of the following areas: commercial, planning and development, human resources, call center, among others. Injection, assembly lines, supply, warehouse and shipping are some examples of the so-called production sectors (data provided by the company). Considering a tolerable sampling error of $4 \%$ for a population of 1,680 workers and with confidence level of 95\%, the minimum sample obtained was 443 workers. ${ }^{15}$ However, the total sample for this study consisted of 885 workers of different sectors and work shifts.

\section{Collection procedures}

The sample selection was performed in two different ways according to the type of work. For workers of administrative sectors, the questionnaire was handed on the workplace and collected after its completion. As for the production sectors, it was agreed with the immediate leadership, a time on the sector's monthly meeting was given so that workers could fill the questionnaire, avoiding possible sample loss. The questionnaire response time ranged from 20 to $30 \mathrm{~min}$.

\section{Variables}

The questionnaire contained demographic information such as gender, age, work shift, marital status and educational level. To 
facilitate the analysis of this research, variables were divided into three blocks (work, health, and leisure).

The variables investigated and the instruments used will be presented below.

Work: Important issues regarding type of work, occupation in other paid activity, leadership position, company time, time working in the current shift, educational level and income. The latter was categorized into tertiles (low, medium and high).

Health: questions elaborated by the author such as health perception, health problems, use of medications, stress perception, presence of pathology, use of medications and sick leaves (absenteeism). Weight status was calculated from self-referred values of body weight and height to calculate BMI and categorized according to cutoff points of the World Health Organization (WHO) as normal weight / underweight (BMI $\left.\leq 24.9 \mathrm{~kg} / \mathrm{m}^{2}\right)$, overweight $\left(\mathrm{BMI} \geq 25.0 \mathrm{~kg} / \mathrm{m}^{2}\right)$ and obese (BMI $\left.\geq 30.0 \mathrm{~kg} / \mathrm{m}^{2}\right)$. The consumption of alcoholic and caffeinated beverages and smoking were also analyzed in the same way.

Physical activity issues were evaluated using the International Physical Activity Questionnaire (IPAQ - short version), prepared with support from the World Health Organization and validated in Brazil by the Center of Studies of the Laboratory of Physical Fitness of São Caetano do Sul - CELAFISCS. ${ }^{16}$ This analysis considered the time of walking, moderate and vigorous physical activity, and sedentary behaviors during the week and on weekends. The following issues related to the sleep-wake cycle investigated were also included in the health block: sleep duration, sleep quality and chronotype. Sleep duration was investigated with questions regarding sleep habits through the instrument proposed by Louzada and Menna-Barreto ${ }^{17}$, which consider the time in bed based on time to sleep and wake up. Sleep duration less than eight hours on weekdays was considered short sleep duration.

Sleep quality was subjectively assessed in relation to last month using the translated and validated for Portuguese of Brazil of the Pittsburgh Sleep Quality Index - (PSQI). ${ }^{18}$ The questionnaire consists of 19 self-administered questions and five questions answered by roommates. The latter are used only for clinical information and were not used in this study. The questions were grouped into seven components: 1) subjective sleep quality; 2) sleep latency; 3) sleep duration; 4) habitual sleep efficiency; 5) sleep disorders; 6) use of medication to sleep; 7) daytime sleepiness and sleep disorders during the day. Weights are distributed on a scale from zero (0) to three (3). The scores of these components were then summed to produce an overall score, which ranges from zero to 21 , in which the higher the score, the worse the sleep quality. Scores above five indicate poor sleep quality and above ten indicate the sleep disorders.

Chronotype (individual tendency to morningness and eveningness) was investigated by questionnaire developed by Horne and Ostberg $^{19}$ (HO), which has been widely used in studies in chronobiology and has been translated and validated for Brazil by Benedito-Silva et al. ${ }^{20}$ It consists of 19 questions that cover different situations of the daily life and the subject is asked to point the personal preferences of time to perform such activities. The score of the questionnaire ranges from 16 to 86 and the individual is classified as: afternoon (extremely afternoon and moderately afternoon), indifferent and morning (moderately morning and extremely morning).

Leisure: The Scale of practices in leisure (Escala de Práticas no Lazer - ELP) ${ }^{21}$ was used to identify leisure experiences according to contents proposed by Dumazedier ${ }^{22}$ (artistic, manual, physical, intellectual and social), Camargo ${ }^{23}$ (tourism) and Schwartz ${ }^{24}$ (virtual) of leisure. In addition to these contents, the scale includes leisure / contemplation item. ${ }^{13,22,25}$ To respond it, the subject should read each item and indicate the most appropriate number to the frequency that he participates in activities in his leisure time, considering " 0 " for "never" participates in activities and "10" for "always" participates in activities.

\section{Data analysis}

Descriptive analyses were performed (means, frequency and standard deviations). For the inferential analysis, the Kruskal-Wallis test was used, and for comparison of means among groups, the chi-square test was used through the SPSS 20.0 statistical software. In order to identify the main differences among groups, the BioEstat 5.0 software was used. The power (P) and effect (ES) of tests were verified using the GPower 3.0 software. The Spearman correlation test was used to correlate continuous variables. A 5\% significance level was adopted.

\section{Ethical aspects}

The study was approved by the Ethics Committee in Research with Human Beings of University of the State of Santa Catarina UDESC in 2014 under protocol number 801.409. So, all ethical procedures for research involving human beings were respected. Workers signed the free informed consent form accepting to participate as voluntary in the survey. Questionnaires were anonymously answered under the supervision of researchers.

\section{RESULTS}

This study analyzed variables related to health, work and leisure, of workers in different work shifts of Florianopolis, SC. The sample characterization is shown in Table 1 . The average age of workers analyzed was 31.1 (8.5) years. It is noteworthy that the majority of the sample (58.2\%) was composed of women with stable relationship (68.2\%) and complete high school (57.7\%).

Regarding the work characteristics, more effective presence of workers in the general shift (73.3\%) and operational tasks (58\%) was observed. On average, the working time in the company investigated was approximately five years. Multiple jobs have been identified in about $8 \%$ of the sample.

With regard to health, in general, the workers exhibited good indicators. Most of the 885 workers analyzed showed positive perception of their health (84.5\%), and reported not making use of any medications (79.3\%) and not being absent from work for health reasons in the last year (83.4\%). Despite these good levels, sleep disorders and obesity were identified in approximately $12 \%$ of the sample.

According to results shown in Table 2, statistically significant associations of work issues among shifts were identified, among them, type of work $(\mathrm{p}<0.001)$, performance of other paid activity $(\mathrm{p}=0.002)$, income $(\mathrm{p}<0.001)$ and educational level $(\mathrm{p}<0.001)$. Differences among shifts were identified in company time $(p=0.033)$ and time in the current shift $(p<0.001)$. These differences were confirmed with the application of the effect size (ES) and test power $(\mathrm{P})$. These analyses showed $\mathrm{ES}=0.151$ and $\mathrm{P}=$ 0.974 for company time and $\mathrm{ES}=0.128$ and $\mathrm{P}=0.905$ for time in the current shift. 
Table 1.

Descriptive analysis of the sample.

\begin{tabular}{|c|c|}
\hline Variables & Indexes \\
\hline Age, years & $31.1(8.5)$ \\
\hline Female, $\%$ & 58.2 \\
\hline \multicolumn{2}{|l|}{ Type of work, \% } \\
\hline Operational & 58.0 \\
\hline Administrative & 42.0 \\
\hline Stable relationship \% & 68.2 \\
\hline \multicolumn{2}{|l|}{ Educational level, \% } \\
\hline Elementary School & 9.8 \\
\hline High school & 57.7 \\
\hline Higher education & 22.0 \\
\hline Postgraduate studies & 10.4 \\
\hline \multicolumn{2}{|l|}{ Work shift, \% } \\
\hline General shift & 73.3 \\
\hline 1st Shift & 11.4 \\
\hline 2nd Shift & 9.5 \\
\hline 3rd Shift & 5.8 \\
\hline No leadership position, $\%$ & 94.6 \\
\hline Does not carry out other paid activity, \% & 92.1 \\
\hline Time in the company, years & $4.9(5.6)$ \\
\hline Time in the turn, months & $4.8(5.6)$ \\
\hline No health problems, $\%$ & 79.0 \\
\hline No use of medication, $\%$ & 79.3 \\
\hline Positive health perception, $\%$ & 84.5 \\
\hline Low perceived stress, \% & 83.6 \\
\hline \multicolumn{2}{|l|}{ Nutritional status, $\%$} \\
\hline Normal weight & 55.8 \\
\hline Overweight & 32.4 \\
\hline Obesity & 11.8 \\
\hline No absence from work, $\%$ & 83.4 \\
\hline Sedentary behavior on weekdays, hours & $7.2(3.2)$ \\
\hline Sedentary behavior over the weekend, hours & $5.2(3.4)$ \\
\hline \multicolumn{2}{|l|}{ Sleep quality, \% } \\
\hline Good sleep quality & 34.5 \\
\hline Poor sleep quality & 54.1 \\
\hline Sleep disorders & 11.4 \\
\hline \multicolumn{2}{|l|}{ Chronotype $\%$} \\
\hline Morning / moderately morning & 26.8 \\
\hline Indifferent & 61.8 \\
\hline Moderately afternoon / afternoon & 11.4 \\
\hline
\end{tabular}

Table 3 shows the analysis of health variables according to work shift. According to presented data, it is possible to identify health risk behaviors in 3rd shift workers. Specifically, in this shift, the prevalence of smoking was $21.6 \%(\mathrm{p}<0.001)$ and $33.3 \%$ of subjects reported consuming three or more cups or glasses of caffeinated drinks per day $(p=0.004)$. Another fact worth mentioning in this shift was that $31.4 \%$ of workers were absent in the last year for health reasons $(p=0.004)$. Nevertheless, these workers spent more time in vigorous physical activities $(\mathrm{p}=0.001, \mathrm{ES}=0.138 ; \mathrm{P}=0.946)$ and less time in sedentary behavior $(\mathrm{p}<0.001, \mathrm{ES}=0.289 ; \mathrm{P}=1.000)$, with approximately 75 minutes and 5 hours per week, respectively. Also in relation to health issues, significant associations were identified about sleep quality $(\mathrm{p}<0.001)$ and chronotype $(\mathrm{p}<0.001)$. The shift with the highest percentage of workers with good sleep quality was the 2 nd shift (46.2\%), and more than $1 / 3$ of 3 rd shift workers had some sleep disorder (35.6\%). Regarding the morningness or eveningness trend (chronotype), data indicate that $16.7 \%$ of 3rd shift workers have morning characteristics and $11.2 \%$ of the general shift had afternoon characteristics. The correlation between company time and HO score (chronotype) was significant $(\mathrm{p}<0.001)$
Table 2.

Variables related to workers working in different shifts.

\begin{tabular}{|c|c|c|c|c|c|}
\hline \multirow[t]{2}{*}{ Labor issues } & \multicolumn{4}{|c|}{ Work shifts } & \multirow[b]{2}{*}{$p$-value* } \\
\hline & $\begin{array}{c}\text { General } \\
\text { shift }\end{array}$ & 1st shift & 2nd shift & 3rd shift & \\
\hline \multicolumn{6}{|l|}{ Type of work, \% } \\
\hline Operational & 47.6 & 85.1 & 81.0 & 98.0 & \multirow{2}{*}{$<0.001$} \\
\hline Administrative & 52.4 & 14.9 & 19.0 & 2.0 & \\
\hline \multicolumn{6}{|l|}{ Other paid activity, \% } \\
\hline Yes & 5.9 & 12.9 & 14.6 & 14.3 & \multirow{2}{*}{0.002} \\
\hline No & 94.1 & 87.1 & 85.5 & 85.7 & \\
\hline \multicolumn{6}{|l|}{ Leadership position, \% } \\
\hline Yes & 6.3 & 4.0 & 1.2 & 3.9 & \multirow{2}{*}{0.205} \\
\hline No & 93.7 & 96.0 & 98.8 & 96.1 & \\
\hline \multicolumn{6}{|l|}{ Income $\%$} \\
\hline Low & 35.0 & 53.8 & 57.9 & 28.9 & \multirow{3}{*}{$<0.001$} \\
\hline Intermediate & 29.9 & 37.4 & 25.0 & 64.4 & \\
\hline High & 35.1 & 8.8 & 17.1 & 6.7 & \\
\hline Time in the company, years & $4.5(5.2) \mathrm{a}$ & $6.1(6.5) a . b$ & 5.0(5.9)a.b & $7.4(6.9) b$ & 0.033 \\
\hline Time in current shift, years & $5.2(5.8) \mathrm{a}$ & $4.0(5.2) \mathrm{b}$ & $3.0(4.1) \mathrm{b}$ & 4.7(5.1)a.b & $<0.001$ \\
\hline \multicolumn{6}{|l|}{ Educational level, } \\
\hline Elementary School & 6.5 & 14.9 & 15.5 & 33.3 & \multirow{4}{*}{$<0.001$} \\
\hline High school & 53.6 & 69.3 & 73.8 & 60.8 & \\
\hline Higher education & 26.2 & 12.9 & 10.7 & 5.9 & \\
\hline Postgraduate studies & 13.7 & 3.0 & 0 & 0 & \\
\hline
\end{tabular}

* Differences between groups with post-hoc Kruskal-Wallis test with Dunne chi-square test; Different letters show statistical differences.

and positive $(\mathrm{r}=0.165)$, indicating that as morningness trend of workers increased, the company time also increased (Figure 1) No differences were found regarding sleep duration in work shifts ( $\mathrm{p}=0.188)$.

With the application of EPL in the sample, it was possible to identify the main preferences in the leisure time of workers (Figure 2). Thus, it was found that virtual activities stand out among leisure activities. This content has obtained the highest score among the other EPL contents (6.4 points), followed by social (6.1 points) and intellectual activities (5.5 points). Among activities with lower frequency, contemplation (3.7 points), tourism (3.2 points) and manual activities (2.8 points), respectively, stand out.

Finally, leisure block analyses are presented in Table 4. These analyses identified significant differences among work shifts in

Figure 1.

Correlation between $\mathrm{HO}$ score and company time.

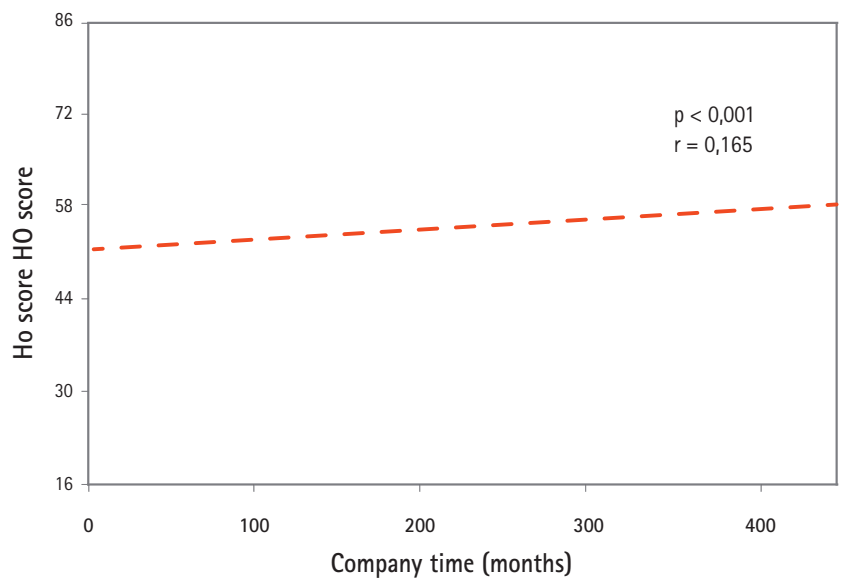


Table 3.

Variables related to the health of workers in different shifts.

\begin{tabular}{|c|c|c|c|c|c|}
\hline Health issues & $\begin{array}{l}\text { General } \\
\text { shift }\end{array}$ & 1st shift & $\begin{array}{l}\text { Work shifts } \\
\text { 2nd shift }\end{array}$ & 3rd shift & $p$-value ${ }^{*}$ \\
\hline \multicolumn{6}{|l|}{ Health perception, \% } \\
\hline Positive & 84.4 & 83.2 & 81.0 & 94.1 & \multirow[t]{2}{*}{0.208} \\
\hline Negative & 15.6 & 16.8 & 19.0 & 5.9 & \\
\hline \multicolumn{6}{|l|}{ Health problems, \% } \\
\hline Yes & 18.2 & 29.7 & 33.3 & 19.6 & \multirow[t]{2}{*}{0.001} \\
\hline No & 81.8 & 70.3 & 66.7 & 80.4 & \\
\hline \multicolumn{6}{|l|}{ Medication use, \% } \\
\hline Yes & 19.3 & 23.8 & 29.8 & 17.6 & \multirow[t]{2}{*}{0.117} \\
\hline No & 80.7 & 76.2 & 70.2 & 82.4 & \\
\hline \multicolumn{6}{|c|}{ Alcohol consumption per week, $\%$} \\
\hline No consumption & 59.9 & 61.4 & 75.0 & 62.7 & \multirow{4}{*}{0.103} \\
\hline 1 to 7 doses & 36.5 & 33.7 & 19.0 & 37.3 & \\
\hline 8 to 14 doses & 2.8 & 5.0 & 4.8 & 0 & \\
\hline 15 doses or more & 0.8 & 0 & 1.2 & 0 & \\
\hline \multicolumn{6}{|l|}{ Smoking, \% } \\
\hline Smoker & 2.6 & 3.0 & 7.3 & 21.6 & \multirow{4}{*}{$<0.001$} \\
\hline Occasional smoker & 3.7 & 4.0 & 3.7 & 7.8 & \\
\hline Former smoker & 6.7 & 12.0 & 2.4 & 3.9 & \\
\hline Not smoker & 87.0 & 81.0 & 86.6 & 66.7 & \\
\hline \multicolumn{6}{|c|}{ Consumption of caffeinated beverages, $\%$} \\
\hline Never & 25.4 & 20.8 & 26.2 & 15.7 & \multirow{4}{*}{0.004} \\
\hline Sometimes & 47.0 & 43.6 & 51.2 & 37.3 & \\
\hline Often & 15.3 & 15.8 & 15.5 & 13.7 & \\
\hline Always & 12.3 & 19.8 & 7.1 & 33.3 & \\
\hline \multicolumn{6}{|l|}{ Stress perception, \% } \\
\hline Low stress & 83.0 & 87.1 & 85.7 & 80.4 & \multirow[t]{2}{*}{0.630} \\
\hline High stress & 17.0 & 12.9 & 14.3 & 19.6 & \\
\hline \multicolumn{6}{|l|}{ Nutritional status, \% } \\
\hline Normal weight & 56.1 & 56.0 & 56.6 & 51.0 & \multirow{3}{*}{0.638} \\
\hline Overweight & 32.2 & 34.0 & 33.7 & 28.6 & \\
\hline Obesity & 11.6 & 10.0 & 9.6 & 20.4 & \\
\hline \multicolumn{6}{|l|}{ Absenteeism, \% } \\
\hline Yes & 14.2 & 21.8 & 20.2 & 31.4 & 0.004 \\
\hline No & 85.8 & 78.2 & 79.8 & 68.6 & \\
\hline Physical activity, $\mathrm{min} / \mathrm{d}$ & day & & & & \\
\hline Walking 3 & $35.8(68.8)$ & $50.4(76.5)$ & $35.2(49.5$ & 61.9(94.3)) & 0.111 \\
\hline Moderate & $45.3(80.8)$ & $60.1(90.4)$ & $51.3(85.1)$ & $63.1(120.7)$ & 0.334 \\
\hline Vigorous & $36.7(66.8) a$ & $62.8(97.7) \mathrm{b}$ & 29.8(67.4)a.b & 75.5(121.5)a.b & 0.001 \\
\hline Sedentary behavior in & the week, & nours & & & \\
\hline & $7.7(3.0) a$ & $6.1(3.6) b$ & $5.8(3.2) b$ & $4.7(2.4) b$ & $<0.001$ \\
\hline Sedentary behavior ove & ver the wee & kend, hours & & & \\
\hline & $5.3(3.4)$ & $5.0(3.2)$ & $5.7(4.0)$ & $4.4(3.0)$ & 0.248 \\
\hline Sleep duration, \% & & & & & \\
\hline Inadequate & 70.1 & 75.0 & 59.3 & 73.5 & 0.188 \\
\hline Adequate & 29.9 & 25.0 & 40.7 & 26.5 & \\
\hline Sleep quality, \% & & & & & \\
\hline Good sleep quality & 36.2 & 29.8 & 46.2 & 6.7 & \\
\hline Poor sleep quality & 53.6 & 63.8 & 41.5 & 57.8 & $<0.001$ \\
\hline Sleep disorders & 10.2 & 6.4 & 12.3 & 35.6 & \\
\hline Chronotype, \% & & & & & \\
\hline Morning / & & & & & \\
\hline Moderately morning & 26.7 & 39.6 & 16.5 & 16.7 & \\
\hline $\begin{array}{l}\text { Indifferent } \\
\text { Moderately }\end{array}$ & 62.1 & 54.5 & 70.9 & 58.3 & $<0.001$ \\
\hline Afternoon / Afternoon & 11.2 & 5.9 & 12.7 & 25.0 & \\
\hline
\end{tabular}

* Differences between groups with post-hoc Kruskal-Wallis test with Dunn test and chisquare; \%: Relative frequency. Distinct letters show statistical differences.
Figure 2.

Average EPL score in differents leisure contents.

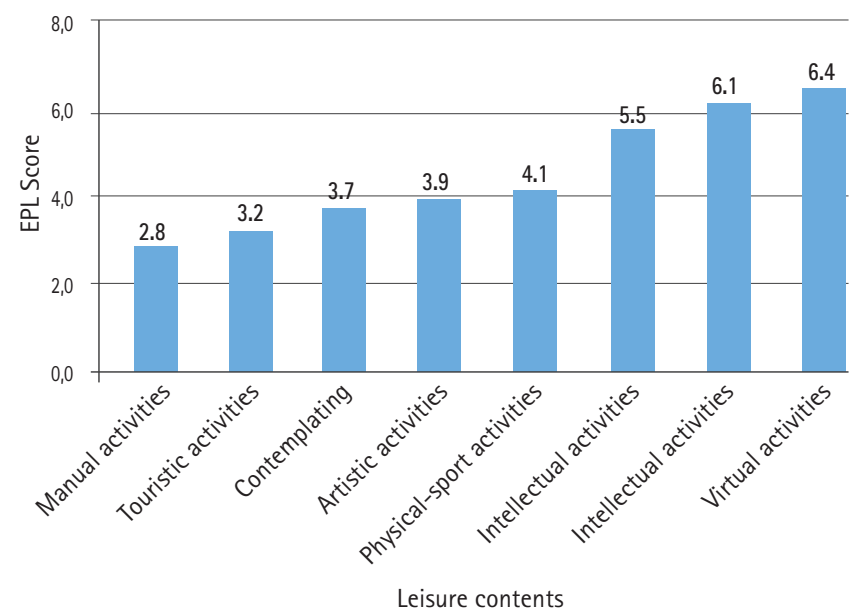

artistic $(\mathrm{p}=0.046, E S=0.159 ; \mathrm{P}=0.985)$, physical-sport $(\mathrm{p}=0.048$; $\mathrm{ES}=0.119 ; \mathrm{P}=0.852)$ and touristic contents $(\mathrm{p}=0.004, \mathrm{ES}=0.178$; $\mathrm{P}=0.996$ ). Dunn's post hoc test was also applied in order to better understand these differences. Thus, statistically significant difference in physical-sport content was observed between general shift and 2nd shift $(\mathrm{p}<0.005)$. In the touristic content, major differences were found between 2 nd shift, general and 1st shifts $(p<0.005)$. For being a more robust test, when the Dunn test was applied for artistic content, the differences between shifts disappeared. For this reason, the Student-Newman-Keuls test was applied for this content. Thus, differences were identified in this content between 2nd shift and general and 1st shifts. It is noteworthy that the 1st shift showed higher values compared to the other shifts in most cultural leisure contents. Only in intellectual and virtual contents, shifts that showed the highest values were the 3rd and 1st shifts, respectively.

Finally, leisure block analyses are presented in Table 4. These analyses identified significant differences among work shifts in artistic $(\mathrm{p}=0.046, E S=0.159 ; \mathrm{P}=0.985)$, physical-sport $(\mathrm{p}=0.048$; $\mathrm{ES}=0.119 ; \mathrm{P}=0.852)$ and touristic contents $(\mathrm{p}=0.004, \mathrm{ES}=0.178$; $\mathrm{P}=0.996$ ). Dunn's post hoc test was also applied in order to better understand these differences. Thus, statistically significant difference in physical-sport content was observed between general shift and 2nd shift $(\mathrm{p}<0.005)$. In the touristic content, major differences were found between 2 nd shift, general and 1st shifts

Table 4.

EPL contents in different shifts.

\begin{tabular}{|c|c|c|c|c|c|}
\hline \multirow[b]{2}{*}{ EPL } & \multirow[b]{2}{*}{$\begin{array}{c}\text { General } \\
\text { shift }\end{array}$} & \multicolumn{2}{|c|}{ Work shifts } & \multirow[b]{2}{*}{ 3rd shift } & \multirow[b]{2}{*}{$p$-value } \\
\hline & & 1st shift & 2nd shift & & \\
\hline Manual & 3.8(3.4) & $4.4(3.6)$ & $4.3(3.8)$ & $4.0(3.7)$ & 0.531 \\
\hline Artistic & $2.9(2.8) a$ & $3.1(2.8) \mathrm{a}$ & $2.5(3.2) b$ & $2.4(2.8) a . b$ & 0.046 \\
\hline Physical-sport & 4.2(3.6)a & 4.5(3.8)a.b & $3.2(3.5) b$ & 3.8(3.5)a.b & 0.048 \\
\hline Intellectual & $5.5(3.2)$ & $5.3(3.3)$ & $5.4(3.8)$ & $6.0(3.6)$ & 0.660 \\
\hline Social & $6.1(3.0)$ & $6.5(3.0)$ & $5.6(3.2)$ & $5.6(3.4)$ & 0.205 \\
\hline Touristic & 3.3(2.9)a & 3.5(3.0)a & $2.5(3.0) \mathrm{b}$ & 2.5(2.9)a.b & 0.004 \\
\hline Virtual & $6.6(3.2)$ & $6.2(3.4)$ & $6.4(3.7)$ & $5.3(3.9)$ & 0.140 \\
\hline Contemplation & $3.7(3.1)$ & $4.2(2.9)$ & 3.4(3.3) & $4.1(3.2)$ & 0.099 \\
\hline
\end{tabular}

* Differences between groups with the Kruskal-Wallis test and post-hoc Dunn's or Student-Newman-Keuls test. Different letters represent significant differences. 
$(\mathrm{p}<0.005)$. For being a more robust test, when the Dunn test was applied for artistic content, the differences between shifts disappeared. For this reason, the Student-Newman-Keuls test was applied for this content. Thus, differences were identified in this content between 2nd shift and general and 1st shifts. It is noteworthy that the 1st shift showed higher values compared to the other shifts in most cultural leisure contents. Only in intellectual and virtual contents, shifts that showed the highest values were the 3rd and 1st shifts, respectively.

\section{DISCUSSION}

The choice for a certain work shift, a priori, should take into account the individual morningness or eveningness characteristics. ${ }^{26}$ However, in practice, the choice for working at night or early in the morning is almost always accompanied by financial or social needs. This inconsistency between individual characteristics and social obligations brings damage to workers' health. The pursuit of science for the understanding of these relationships, especially with those of the night shift is not new. ${ }^{27}$ However, much of the scientific literature on this area is aimed at investigating health professionals, especially nurses. ${ }^{28}$ Given this gap, this study showed differences in work, health and leisure aspects with a population of industry workers from different shifts.

With regard to health issues, sleep quality is undoubtedly essential to a good quality of life and as a protective factor for numerous diseases. $^{29}$ Considered one of the biological rhythms essential to human life, it is believed that humans cannot survive for long periods with sleep deprivation. ${ }^{30}$ This circadian rhythm (which is repeated around 24 hours) is synchronized by endogenous processes of the nervous system and with the influence of the environment (light / dark). Thus, social activities such as work at night cause a "desynchronization" in the circadian rhythm of sleep and may lead to serious impairment of physiological and psychological functions. ${ }^{31}$ Given the above, in this study, night shift workers showed poorer sleep quality in relation to workers from other shifts. Nevertheless, differences with regard to duration were not found. Thus, daytime sleep does not seem to be satisfactory enough to repair the waking hours in nighttime activities. In addition, in research with retired workers, Guo et $\mathrm{al}^{32}$ found that the effects on sleep quality can return to normal levels after 20 years of shift work interruption. The authors reported that the first years are the most difficult times for shift workers for the adjustment of circadian rhythms.

Another factor to be considered in this process is the chronotype of each individual. The combination of genetic elements and sociodemographic, environmental and individual factors results in the preference for afternoon or morning social behaviors. ${ }^{33}$ In this study, differences were identified in all shifts with respect to chronotype. However, in the sample analyzed, it was found that approximately $17 \%$ of night shift workers have morning characteristics and about 12\% of workers who begin their activities at 7:30 am have afternoon characteristics. This misalignment can be reflected in work yield, sleep quality, social activities and increased risk of accidents. $^{34}$ Accordingly, when workers were asked if they had been absent from work for health reasons in the last year, approximately $32 \%$ of shift workers confirmed absenteeism. On the other hand, in the other work shifts, this percentage was lower. Thus, working in day shifts seems to cause fewer health problems and sick leaves than night shift.
When considering the entire sample, the percentage of morning and afternoon workers is similar to the findings of Lyons et al. ${ }^{35}$ In this research, the sample was composed of students from a university in southern Brazil. Researchers identified from the application of this instrument ${ }^{19}$, 32\% of afternoon, 54\% of intermediate and 14\% of morning characteristics, unlike 11.5\%, 61.8\% and $26.8 \%$ of this study, respectively. Thus, the morningness or eveningness trend may influence work and even the company time. This hypothesis is supported by the correlation between HO and company time (Figure 1) and contributes to explain that the chronotype distribution of this sample is different from the general population. Anyway, shift work based on chronotype may reduce the disruption of the circadian cycle and improve sleep and the potential long-term effects on workers' health. ${ }^{36}$ Also with respect to issues related to workers' health, the adoption of risk behaviors also showed differences according to work shift. Cigarette smoking, for example, was statistically different among shifts. Among night workers, 21.6\% of the sample declared themselves as smokers. This index is worrying, considering that in a national survey, this prevalence was 13\%, the same percentage considering only the southern states of Brazil. ${ }^{37}$

In addition, one third of 3rd shift workers reported excessive consumption of caffeinated beverages. Although the consumption of this substance plays a potential role in promoting alertness during waking periods, especially for night workers, its long-term effects are unclear. $^{38}$ Thus, there is no reason for healthy individuals who ingest caffeine within recommended levels to increase its consumption in order to improve alertness. With regard to sedentary behavior, the main differences were identified among workers of the general shift and shift workers. Those who have their work duties in usual times (morning and afternoon) have more time in sedentary behavior on weekdays. This inequality could be explained by the fact that shift workers have a time of day available for physical activities. However, this explanation was not confirmed in the analysis of physical activities. Only vigorous physical activity showed differences between the general shift and the 1st shift. In addition, the time of vigorous physical activity among 3rd shift workers were 75.5 (121.5) minutes. This analysis stems from the subjective perception of exertion in relation to the physical activity performed. Thus, it is believed that the work performed at night requires greater physical effort when performed by day workers. In addition, the analysis of walking and moderate activity time did not confirm the same differences found in sedentary behaviors.

Nevertheless, in the analysis of preferences of physical and sports activities at leisure time, differences between the general shift and the 2nd shift were identified, with indexes of 4.2 (3.6) and 3.2 (3.5), respectively, which corroborates a recent research carried out with sample of Australian adults. In this research, shift workers reported doing less physical activity during leisure time. ${ }^{39}$ Thus, this relationship deserves further clarification, as other factors may be associated with sedentary behavior on weekdays, among them, sociodemographic and psychosocial characteristics and type of work performed.

Trying to find answers to these relationships, Saidj et $\mathrm{al}^{40}$ evaluated 35,444 French workers and concluded that sedentary behaviors in the work environment may be associated with physical inactivity out of it. This could suggest that the fact of having a job with sedentary features such as administrative work is not compensated with active behavior outside work. However, researchers are 
careful when analyzing these relationships, and, similarly, they add that other factors may influence sedentary behavior, including socioeconomic status and educational level.

In the company analyzed, for administrative sectors, mostly composed of workers of the general shift, higher education is required, but in operational positions, usually composed of shift workers, complete high school is enough. Thus, differences among shifts were also observed with respect to educational level and income. Thus, the income of shift workers was lower, which explains the increased demand for second job to supplement family income.

These factors may also explain differences in the preferences of leisure activities, especially in the touristic content. According to Marcellino ${ }^{13}$, knowing new places, people, cultures and landscapes positively impact workers' health. However, despite the improvements in income conditions in recent years, with significant increase in international flights ${ }^{41}$, representing greater access to tourism, the results of this study indicate that such activity is not yet configured as a routine among lower-income workers.

Also in relation to leisure content, although no differences among shifts were found, it is noteworthy that virtual leisure contents had higher preference among workers analyzed (Figure 2). Such activities have gained prominence in recent years with advances in technology, making it a cultural content of leisure ${ }^{24}$, especially with digital games, internet and recently smartphones. Experts recommend caution in the use of these resources, because the consequences of their excess use are still unclear. However, one of the most accepted hypothesis is that their uncontrolled use can cause dependence ${ }^{42}$, psychological problems ${ }^{43}$ and social isolation $^{44}$, which is in line with objects of leisure practices that are personal and social development and fun. ${ }^{45}$

The present study showed improvements in the description of differences in the work characteristics and health of industry workers. In addition, the use of EPL enabled the identification of leisure preferences in its different content of industry workers. Nevertheless, the main limitation of this study is the use of subjective measures of physical activity and sleep. Thus, new research with accelerometry and polysomnography are recommended to better explain this form of work and its consequences to minimize damages to workers' health.

\section{CONCLUSION}

The meaning of shift work goes beyond a simple choice to work during the day or night. Substantial consequences on aspects related to health, leisure and work were shown. Overall, the main differences have been identified in relation to night work, with more smoking, higher consumption of caffeinated beverages, sleep disorders and sick leave due to health problems.

Theoretically, having working hours less than usual ( $<44$ hours), could create opportunities for workers a better use of leisure activities. However, the major inequalities found among shifts were only in artistic, physical-sport and touristic content. Thus, low pay can be a determining factor in this process.

Shift workers, in general, have lower income and educational level, thus requiring a second job to supplement income. In this way, more than the time available for activities, socioeconomic factors are determinant for leisure experiences.

Therefore, further studies on issues related to the work and leisure binomial should be carried out to better understand this relationship. In addition, the company should adopt specific actions of preventive behaviors and sleep hygiene of workers, especially those who work at night.

\section{REFERENCES}

1. Zanelli JC, Borges-Andrade JE, Bastos AVB. Psicologia, Organizações e Trabalho no Brasil. Porto Alegre: Artmed; 2014.

2. Fullick $S$, Grindey $C$, Edwards B, Morris $C$, Reilly $T$, Richardson D, et al. Relationships between leisure-time energy expenditure and individual coping strategies for shift-work. Ergonomics. 2009;52(4):448-55.

3. Fischer FM, Rotenberg L, Moreno CRdC. Trabalho em turnos e noturno: impactos sobre o bem-estar e saúde dos trabalhadores. Possiveis intervenções. In: Patologia do trabalho. 3ed ed. vol 1. São Paulo: Atheneu; 2013. p.753-782.

4. Silva IMSd, Prata JSR, Ferreira AIMA. Horários de trabalho por turnos: da avaliação dos efeitos às possibilidades de intervenção. Int J Working Condit. 2014;7:70-83.

5. Ulhoa MA, Marqueze EC, Burgos LGA, Moreno CRC. Shift Work and Endocrine Disorders. Int J Endocrinol. 2015; (Mar):1-11.

6. Benedito-Silva A. Cronobiologia do ciclo vigília-sono. In: Tufik S. Medicina e Biologia do Sono. São Paulo: Manole; 2008. p. 24-33.

7. Paiva T, Penzel T. Centro de medicina do sono: Manual prático. Lisboa: Lidel; 2011.

8. Oliveira Bd, Martino MMFd. Análise das funções cognitivas e sono na equipe de enfermagem nos turnos diurno e noturno. Rev Gaúcha Enferm. 2013;34(1):30-36.
9. Prata J, Silva IS. Efeitos do trabalho em turnos na saúde e em dimensões do contexto social e organizacional: um estudo na indústria eletrônica. Rev Psicol Organ Trab. 2013;13(2):141-154.

10. IARC Working Group on the Evaluation of Carcinogenic Risks to Humans. Painting, firefighting, and shiftwork. Lyon: WHO-IARC; 2010. (IARC Monographs on the Evaluation of Carcinogenic Risks to Humans; 98).

11. Griep RH, Bastos LS, Mendes da Fonseca MdJ, Silva-Costa A, Portela LF, Toivanen $\mathrm{S}$, et al. Years worked at night and body mass index among registered nurses from eighteen public hospitals in Rio de Janeiro, Brazil. BMC Health Serv Res. 2014;14:603.

12. Barnes-Farrell JL, Davies-Schrils K, McGonagle A, Walsh B, Di Milia L, Fischer $F M$, et al. What aspects of shiftwork influence off-shift well-being of healthcare workers? Appl ergon. 2008;39(5):589-96.

13. Marcellino NC. Estudos do lazer: uma introdução. Sao Paulo: Autores Associados; 2012.

14. Gil AC. Como elaborar projetos de pesquisa. 5a ed. São Paulo: Atlas; 2010.

15. Rodrigues PC. Bioestatística. 2a ed. Rio de Janeiro: EDUFF; 2002.

16. Pardini $R$, Matsudo $S$, Araújo $T$, Matsudo $V$, Andrade $E$, Braggion $G$, et al. Validação do questionário internacional de nível de atividade física (IPAQversão 6): estudo piloto em adultos jovens brasileiros. Rev Bras Ciên e Mov. $2001 ; 9(3): 45-51$ 
17. Louzada F, Menna-Barret L. Sleep-wake cycle in rural populations. Biol Rhythm Res. 2004;35(1-2):153-157.

18. Bertolazi AN, Fagondes SC, Hoff LS, Dartora EG, da Silva Miozzo IC, Ferreira de Barba ME, et al. Validation of the Brazilian Portuguese version of the Pittsburgh Sleep Quality Index. Sleep Med. 2011;12(1):70-75.

19. Horne $J A$, Ostberg 0 . A self-assessment questionnaire to determine morningness-eveningness in human circadian rhythms. Int J Chronobiol. 1976;4(2):97-110.

20. Benedito-Silva A, Menna-Barreto L, Marques N, Tenreiro S. A selfassessment questionnaire for the determination of morningness eveningness types in Brazil. Prog Clin Biol Res. 1990;341B:89-98.

21. Andrade R, Schwartz G, Tavares G, Pelegrini A, Teixeira C, Felden É. Validade de construto e consistência interna da Escala de Práticas no Lazer para adultos. Ciên Saúde Colet.[on line] 2016 [citado nov 2017];(Mai):00. Disponivel em: http://www.cienciaesaudecoletiva.com.br/artigos/validade-deconstruto-e-consistencia-interna-da-escala-de-praticas-no-lazer-paraadultos $/ 15625$ ? id $=15625$.

22. Dumazedier J, Mazza S, Guinsburg J, Martins Filho P, Bolognani VL. Sociologia empírica do lazer. Sao Paulo: Edcs. SESC; 1979.

23. Camargo LOdL. Educação para o lazer. São Paulo: Moderna; 1998.

24. Schwartz GM. 0 conteúdo virtual do lazer: contemporizando Dumazedier. Licere. 2003; 2(6):23-31.

25. Lafargue P. 0 direito a preguiça: a religião do capital. Sao Paulo: Kairós Livraria; 1983.

26. Moreno CRdC, Fischer FM, Rotenberg L. A saúde do trabalhador na sociedade 24 horas. São Paulo Perspec. 2003;17(1):34-46.

27. Cipolla Neto J, Marques N. Introdução ao estudo da cronobiologia. Sao Paulo: Icone; 1988.

28. Gemelli KK, Hilleshein EF, Lautert L. Efeitos do trabalho em turnos na saúde do trabalhador: revisão sistemática. Rev Gaúcha Enferm. 2008; 29(4):639646.

29. Palhares VdC, Corrente JE, Matsubara BB. Association between sleep quality and quality of life in nursing professionals working rotating shifts. Rev Saude Publica. 2014;48(4):594-601.

30. Parthasarathy $S$, Vasquez MM, Halonen M, Bootzin R, Quan SF, Martinez FD, et al. Persistent Insomnia is Associated with Mortality Risk. Am J Med. 2015;128(3):268-275e2.

31. Pereira $\dot{E}_{1}$ Anacleto $T$, Louzada $F$. Interação entre sincronizadores fóticos e sociais: repercussões para a saúde humana. Rev Biol. 2012;9(3):68-73.
32. Guo 0, Wu B, Chen W, Zhang $Y$, Wang J, Li X. Effects of nitric oxide treatment on the cell wall softening related enzymes and several hormones of papaya fruit during storage. Food Sci Technol Int. 2014;20(4):309-317.

33. Benedito-Silva AA, Menna-Barreto L, Alam MF, Rotenberg L, Moreira LFS, Menezes $A A L$, et al. Latitude and social habits as determinants of the distribution of morning and evening types in Brazil. Biol Rhythm Res. 1998;29(5):591-597.

34. Gamble KL, Motsinger-Reif AA, Hida A, Borsetti HM, Servick SV, Ciarleglio $\mathrm{CM}$, et al. Shift Work in Nurses: Contribution of Phenotypes and Genotypes to Adaptation. Plos One. 2011;6(4):e18395.

35. Lyons E, Pedersen B, Kane J, Alam M, Ming R, Tang $H$, et al. Finding and comparing syntenic regions among Arabidopsis and the outgroups papaya, poplar, and grape: CoGe with rosids. Plant Physiol. 2008;148(4):1772-1781.

36. Vetter C, Fischer D, Matera JL, Roenneberg T. Aligning work and circadian time in shift workers improves sleep and reduces circadian disruption. Curr Biol. 2015;25(7):907-911.

37. Nahas M. Estilo de vida e hábitos de lazer dos trabalhadores das indústrias brasileiras. Brasília: Serviço Social da Indústria; 2009.

38. Ker K, Edwards PJ, Felix LM, Blackhall K, Roberts I. Caffeine for the prevention of injuries and errors in shift workers. Cochrane Database of Systematic Reviews. 2010; 12(5):CD008508.

39. Vandelanotte C, Short C, Rockloff M, Di Millia L, Ronan K, Happell B, et al. How do different occupational factors influence total, occupational, and leisure-time physical activity? J Phys Act Health. 2015; 12(2):200-207.

40. Saidj M, Menai M, Charreire $H$, Weber $C$, Enaux C, Aadahl M, et al. Descriptive study of sedentary behaviours in 35,444 French working adults: crosssectional findings from the ACTI-Cites study. BMC Public Health. 2015; 15:379.

41. Meurer R. Determinantes Macroeconômicas das Despesas de Viagens Internacionais do Brasil. Planej Polít Públicas. 2014;(42):363-390.

42. Kelleci M, Inal S. Psychiatric Symptoms in Adolescents with Internet Use: Comparison without Internet Use. Cyberpsych Beh Soc N. 2010;13(2):191194.

43. Kotikalapudi R, Chellappan S, Montgomery F, Wunsch D, Lutzen K. Associating depressive symptoms in college students with internet usage using real Internet data. IEEE Technol Soc Mag. 2012;31(4):73-80.

44. Yao MZ, Zhong Z-j. Loneliness, social contacts and Internet addiction: A cross-lagged panel study. Comput Hum Behav. 2014;30:164-70.

45. Requixa R. Conceito de lazer. Rev Bras Educ Fis Desportos. 1979;(42):11-21. 